\title{
Process development of ATROSAB, an anti TNFR1 Monoclonal Antibody: in three steps from research to GMP
}

\author{
Karlheinz Landauer ${ }^{1 *}$, Cuneyt Unutmaz ${ }^{1}$, Simon Egli ${ }^{1}$, Verena Berger ${ }^{2}$, Simone Lais ${ }^{1}$, Timo Liebig ${ }^{1}$, Daniel Steiner ${ }^{1}$, \\ Jo Maier ${ }^{1}$, Ina Rostalski ${ }^{1}$, Francois Forcellino ${ }^{1}$, Andreas Herrmann ${ }^{1,2}$ \\ From 22nd European Society for Animal Cell Technology (ESACT) Meeting on Cell Based Technologies \\ Vienna, Austria. 15-18 May 2011
}

The humanized monoclonal antibody ATROSAB is targeting specifically the TNF receptor 1 (TNFR1). TNF is a central mediator of inflammation and key target for intervention in inflammatory diseases such as rheumatoid arthritis, psoriasis and Crohn's Diseases. Notably, blockade of the second TNF receptor, TNFR2, has been associated with increased sensitivity to viral infections or increased susceptibility to demyelinating disorders and lymphomas. In this context, a selective inhibition of TNF-induced TNFR1 but not TNFR2 signaling activity holds great promises to overcome undesired effects observed with less specific TNF antagonists currently used in clinic.

The recently humanized antibody was used to establish a rCHO-K1 cell line under serum-free, chemically defined conditions (1). The process development was based on two sets of shake flask experiments, three 10L bioreactor runs and finally 2 GMP production runs in $300 \mathrm{~L}$ scale. The scale up strategy was based on quality by design considerations specified in the design space for the scale-up parameters. The main parameter for the scale-up development was mixing time as a function of the bioreactor geometry, tip-speed, Reynolds number, and the power input of the systems. Those parameters are generally considered as important parameters during up-stream process development.

Protein characteristics were specified based on several considerations. A major part was the ICH-Q8 guideline as well as antibody and other drug guidelines. The other part is based on experience with antibody development and the specific protein in special. The specifications are

\footnotetext{
* Correspondence: Karlheinz.Landauer@celonic.ch

'Celonic AG, Basel, Switzerland

Full list of author information is available at the end of the article
}

described in Table 1. The analytical methods used to characterize the antibody were SDS-PAGE, western blot, HPLC-SEC, protein A HPLC, HPAEC-PAD, Isoelectric focusing and a cell based potency assay. As the antibody is declined to bind to the TNF-R1 on target cells, it was engineered not to elicit ADCC or CDC. Therefore those parameters were not checked during process development.

The basal medium was fixed to a commercial available chemically defined medium during clone screening. In a batch process, performed in a fully equipped $1 \mathrm{~L}$ bioreactor, a titer of approximately $180 \mathrm{mg} / \mathrm{L}$ was obtained. At this stage the antibody was characterized and specifications were partly narrowed and some were newly set. In the first step of process development different feeding solutions and concentrations thereof were tested in shake flask experiments. Metabolite data were monitored on a daily basis comprising glucose, lactate, ammonia, and amino acid levels. Additionally cell density and protein concentration were measured at the same time interval. For in-depth protein characterization, supernatant was purified after 6 days of fermentation and at harvest, in order to check the quality attributes already early at the development stage. This step led to an increase of about 2.5 fold in product concentration, while the protein characteristics stayed within specifications at both sampling time points. The second step was the optimization of the feeding strategy as well as the fortification of the solutions with certain chemically defined supplements. This led to another increase of about 2.5 fold regarding final product concentration. Product quality changed slightly, but stayed within specifications. Especially the glycosylation structure changed towards less glycosylated versions. 
Table 1 specified scale-up parameters and defined protein characteristics

\begin{tabular}{|c|c|c|c|c|}
\hline \multirow[b]{2}{*}{ Parameter } & \multicolumn{2}{|c|}{ scale-up parameter } & \multicolumn{2}{|c|}{ protein characteristics } \\
\hline & Design Space & 300L GMP & $\begin{array}{l}\text { specifications defined at the } \\
\text { project start }\end{array}$ & 300L GMP \\
\hline Mixing Time [s] & $10-70$ & $\max .60$ & Isoforms (IEF) & $\mathrm{pH} 7.6-8.8$ \\
\hline Tip-Speed [m/s] & $0.6-1.2$ & $\max .1 .0$ & $\begin{array}{l}\text { Glycosylation } \\
\text { (HPAEC-PAD) }\end{array}$ & $\begin{array}{c}\text { Mol\% of different forms } \pm 20 \% \text { from clone } \\
\text { screening }\end{array}$ \\
\hline $\begin{array}{l}\text { Reynolds } \\
\text { Number }\end{array}$ & $1-8$ Mio & max. 6 Mio & Potency & $40 \%-160 \%$ from clone screening \\
\hline $\begin{array}{l}\text { Power Input [W/ } \\
\text { m3] }\end{array}$ & $25-1100$ & $\max .650$ & $\begin{array}{l}\text { Molecular weight } \\
\text { (SDS-PAGE) }\end{array}$ & Main Band at app. $150 \mathrm{kDa}$ \\
\hline Gassing & $\begin{array}{l}\text { Head Space / Ring } \\
\text { Sparger }\end{array}$ & $\begin{array}{l}\text { Head Space \& Ring } \\
\text { Sparger }\end{array}$ & Immunogenic glycostructures & none \\
\hline Agitation & orbital sh., Rushton I. & Rushton I. & Purity (HP-SEC) & $>90 \%$ \\
\hline
\end{tabular}

However, no impact on the bioassay was observable. The process was finally scaled up to the $300 \mathrm{~L}$ stirred tank bioreactor in the GMP facility. An engineering run was performed to test the process and product parameters. Some influence was measured, thus the process was slightly changed prior the first GMP run. The obtained product quality was well within specifications, the achieved titer was more than $1.2 \mathrm{~g} / \mathrm{L}$, which was a more than 7 fold increase in comparison to the initial batch process. Although the cell density profile of the process changed between run 1 and 2, the volumetric product concentration was only slightly below $1.2 \mathrm{~g} / \mathrm{L}$ and the product characteristics were identical to the first run. This indicates the robustness of the developed process and the validity to define and specify design spaces for process development especially during scaleup development. The analysis of protein characteristics employing SDS-PAGE, IEF, HP-SEC, potency assay and glycosylation pattern with HPAEC-PAD ensures the quality of the protein.

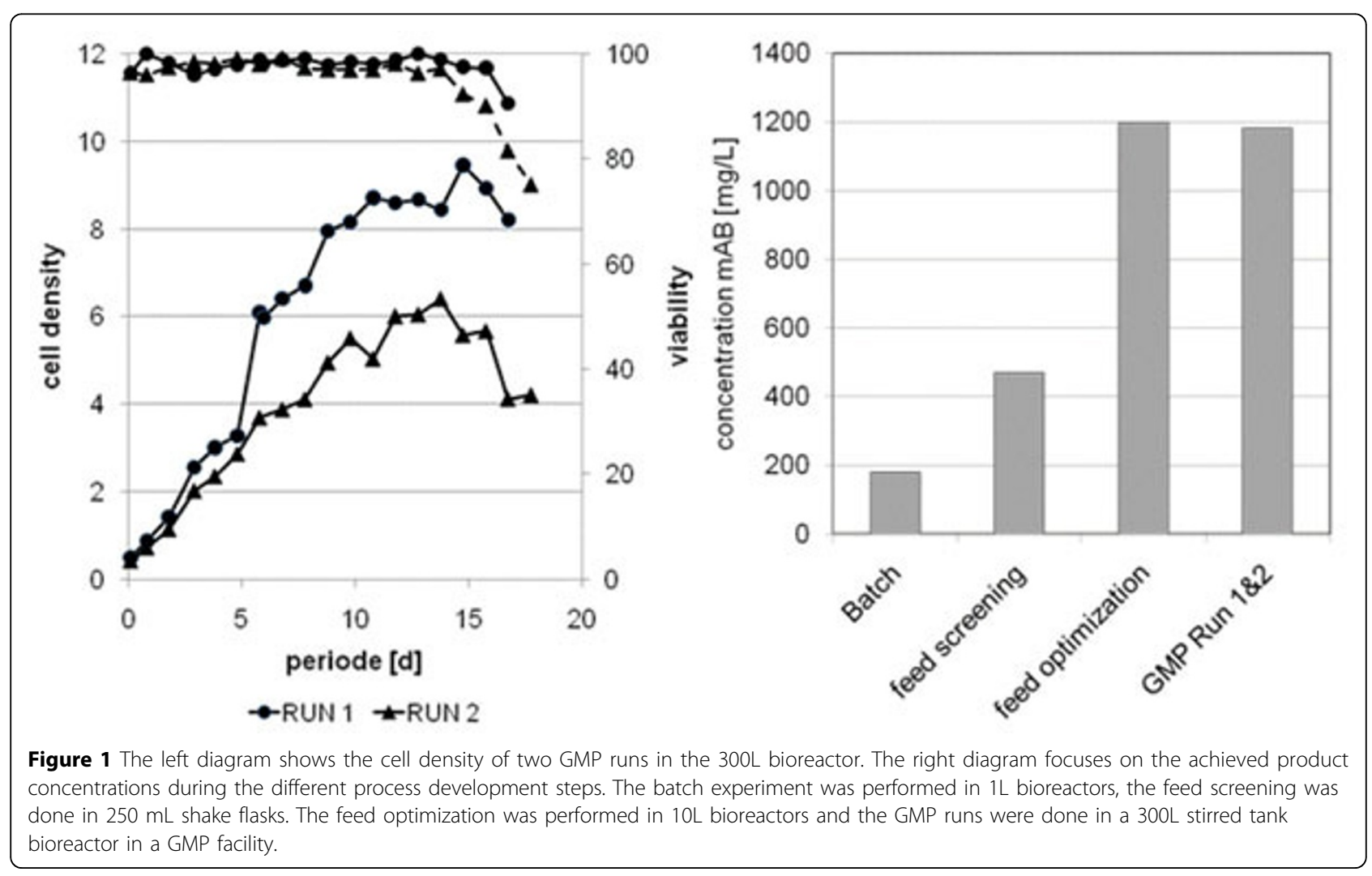




\section{Author details}

${ }^{1}$ Celonic AG, Basel, Switzerland. ${ }^{2}$ Celonic GmbH, Jülich, Deutschland.

Published: 22 November 2011

\section{Reference}

1. Zettlitz KA, Lorenz V, Landauer K, Münkel S, Herrmann A, Scheurich P,

Pfizenmaier $\mathrm{K}$, Kontermann R: ATROSAB, a humanized antagonistic antitumor necrosis factor receptor one-specific antibody. mAbs 22010 , 2(6):639-647.

doi:10.1186/1753-6561-5-S8-P42

Cite this article as: Landauer et al: Process development of ATROSAB, an anti TNFR1 Monoclonal Antibody: in three steps from research to GMP. BMC Proceedings 2011 5(Suppl 8):P42.

Submit your next manuscript to BioMed Central and take full advantage of:

- Convenient online submission

- Thorough peer review

- No space constraints or color figure charges

- Immediate publication on acceptance

- Inclusion in PubMed, CAS, Scopus and Google Scholar

- Research which is freely available for redistribution

Submit your manuscript at www.biomedcentral.com/submit
Ciomed Central 